\title{
Effect of Algae and Plant Lectins on Planktonic Growth and Biofilm Formation in Clinically Relevant Bacteria and Yeasts
}

\author{
Mayron Alves Vasconcelos, ${ }^{1,2}$ Francisco Vassiliepe Sousa Arruda, ${ }^{3}$ Victor Alves Carneiro, ${ }^{1}$ \\ Helton Colares Silva, ${ }^{1}$ Kyria Santiago Nascimento, ${ }^{1}$ Alexandre Holanda Sampaio, ${ }^{1}$ \\ Benildo Cavada, ${ }^{1}$ Edson Holanda Teixeira, ${ }^{3}$ Mariana Henriques, ${ }^{2}$ and Maria Olivia Pereira ${ }^{2}$ \\ ${ }^{1}$ Biologically Active Molecules Laboratory (Biomol-Lab), Department of Biochemistry and Molecular Biology, \\ Federal University of Ceará, Fortaleza 60440-970, CE, Brazil \\ ${ }^{2}$ Institute for Biotechnology and Bioengineering (IBB), Center of Biological Engineering, University of Minho, \\ 4710-057 Braga, Portugal \\ ${ }^{3}$ Integrated Laboratory of Biomolecules (LIBS), Department of Pathology and Legal Medicine, Faculty of Medicine, \\ Federal University of Ceará, Fortaleza 60430-160, CE, Brazil \\ Correspondence should be addressed to Edson Holanda Teixeira; edsonlec@gmail.com
}

Received 19 February 2014; Revised 29 April 2014; Accepted 14 May 2014; Published 28 May 2014

Academic Editor: Xiaoling Miao

Copyright (c) 2014 Mayron Alves Vasconcelos et al. This is an open access article distributed under the Creative Commons Attribution License, which permits unrestricted use, distribution, and reproduction in any medium, provided the original work is properly cited.

\begin{abstract}
This study aimed to evaluate the abilities of plant and algae lectins to inhibit planktonic growth and biofilm formation in bacteria and yeasts. Initially, ten lectins were tested on Staphylococcus epidermidis, Staphylococcus aureus, Klebsiella oxytoca, Pseudomonas aeruginosa, Candida albicans, and C. tropicalis at concentrations of 31.25 to $250 \mu \mathrm{g} / \mathrm{mL}$. The lectins from Cratylia floribunda (CFL), Vatairea macrocarpa (VML), Bauhinia bauhinioides (BBL), Bryothamnion seaforthii (BSL), and Hypnea musciformis (HML) showed activities against at least one microorganism. Biofilm formation in the presence of the lectins was also evaluated; after $24 \mathrm{~h}$ of incubation with the lectins, the biofilms were analyzed by quantifying the biomass (by crystal violet staining) and by enumerating the viable cells (colony-forming units). The lectins reduced the biofilm biomass and/or the number of viable cells to differing degrees depending on the microorganism tested, demonstrating the different characteristics of the lectins. These findings indicate that the lectins tested in this study may be natural alternative antimicrobial agents; however, further studies are required to better elucidate the functional use of these proteins.
\end{abstract}

\section{Introduction}

Microorganisms are able to grow and adhere to many surfaces, forming complex communities known as biofilms. In biofilms, cells grow in multicellular aggregates that are encased in a self-produced extracellular matrix [1]. Moreover, it is known that these microcommunities exhibit distinct phenotypes with respect to gene transcription, growth rate, and enhanced resistance to antimicrobial agents [2-4].

Biofilms have been found to be involved in many chronic diseases, such as chronic otitis, tonsillitis, cystic fibrosis, periodontal diseases, and urinary tract infections [5-7]. Furthermore, biofilms can form on medical implants such as catheters, artificial hips, and contact lenses, and, owing to their increased resistance to antimicrobial agents, these infections can often only be treated by removing the device [ 8 , 9]. Compared to their planktonic counterparts, the microorganisms in biofilms are less sensitive to biocides and antibiotics, complicating the management of device-associated infections and limiting therapeutic options [10, 11]. Thus, the discovery of new compounds that are able to eradicate such biofilms is critical. In fact, in recent years, lectins have been demonstrated to be active compounds against bacteria and fungi in both planktonic cells and biofilms [12-14].

Lectins are a class of carbohydrate-binding proteins of nonimmune origin which are organized into closely structurally related families [15]. Although lectins were first found in plants, they occur in all classes and families of organisms, 
from bacteria and viruses to mammals [16-18]. They are responsible for deciphering sugar codes through complex surface interactions and play a central role in a number of biological processes, such as infections, cell communication, and cell growth $[19,20]$. Based on their capacity to bind and recognize specific carbohydrates, lectins are involved in several biological activities [21-25]. Although lectins have sequence homology and structural similarities, they differ in their various biological properties [26]. Thus, it is important to identify new lectins with biotechnological potential as antimicrobial and antibiofilm agents.

Lectins can recognize and reversibly bind to carbohydrates on cell surfaces and interact with cell wall polysaccharides and/or glycoconjugates in the cell membrane [27, 28]. Moreover, lectins can interact with bacterial lipopolysaccharides (LPS) or with the extracellular matrix of microorganisms [29-31]. Some lectins have also shown antimicrobial activity and are able to interfere with the formation of biofilms [14, 32-36].

Thus, this work aimed to evaluate the in vitro antimicrobial activity of a set of plant and red algae lectins towards clinically relevant microorganisms, including bacteria and yeast.

\section{Materials and Methods}

2.1. Microorganisms. The microorganisms used in this study included gram-positive bacteria: Staphylococcus epidermidis CECT231 and Staphylococcus aureus JKD 6008, gramnegative bacteria: Klebsiella oxytoca ATCC13182 and Pseudomonas aeruginosa ATCC 10145, and yeasts: Candida albicans ATCC90028 and Candida tropicalis ATCC750, which were obtained from the Colección Española de Cultivos Tipo (CECT) and the American Type Culture Collection (ATCC). The $S$. aureus strain JKD6008 is a clinical isolate that has developed resistance to vancomycin (vancomycinintermediate $S$. aureus (VISA)) [37].

2.2. Lectins Purification. The plant and algae lectins were isolated by different chromatographic techniques including affinity and ion exchange chromatographies. The references for purification are described as follows: Dioclea megacarpa lectin (DML) [38], Dioclea rostrata lectin (DRL) [39], Dioclea guianensis lectin (DGL) [40], Dioclea violacea lectin (DVL) [41], Cratylia floribunda lectin (CFL) [42], Vatairea macrocarpa lectin (VML) [43], Bauhinia bauhinioides lectin (BBL) [44], Luetzelburgia auriculata agglutinin (LAA) [45], Bryothamnion seaforthii lectin (BSL) [46], and Hypnea musciformis lectin (HML) [47].

2.3. Culture Conditions. The bacteria were grown in Trypticase Soy Agar medium (TSA, Liofilchem, Italy) and incubated at $37^{\circ} \mathrm{C}$ for $24 \mathrm{~h}$. After growth on solid medium, an isolated colony was removed and inoculated into $10 \mathrm{~mL}$ of Trypticase Soy Broth (TSB, Liofilchem, Italy) and incubated for $18 \mathrm{~h}$ at $37^{\circ} \mathrm{C}$ under constant agitation at $120 \mathrm{rpm}$. Prior to use, the cell concentration of each inoculum was adjusted to $2 \times 10^{6}$ cells $/ \mathrm{mL}$ using a spectrophotometer $(620 \mathrm{~nm})$ and the calibration curves previously determined for each bacterium. The yeast culture conditions were the same as those previously mentioned; however, the media included Sabouraud Dextrose Agar and Broth (SDA and SDB, respectively; Liofilchem, Italy), and the concentration of each yeast inoculum was adjusted to $2 \times 10^{6}$ cells $/ \mathrm{mL}$ using a Neubauer chamber.

2.4. Planktonic Growth Assays. The effects of lectins on planktonic growth were determined by the broth microdilution method in 96-well polystyrene plates. Briefly, lectins were diluted in culture medium (SDB for yeasts and TSB for bacteria) to concentrations of 31.25 to $250 \mu \mathrm{g} / \mathrm{mL}$, and $100 \mu \mathrm{L}$ of each lectin was incubated with $100 \mu \mathrm{L}$ of each microorganism (previously adjusted to $2 \times 10^{6}$ cells $/ \mathrm{mL}$ ). In order to provide a negative control, similar assays were performed without lectins. All plates were incubated at $37^{\circ} \mathrm{C}$ for $24 \mathrm{~h}$ at $120 \mathrm{rpm}$, and optical density of each well was recorded at $640 \mathrm{~nm}\left(\mathrm{OD}_{640}\right)$ using an automated microplate reader (Synergy TM HT Multidetection Microtiter Reader). The inhibition of planktonic growth by lectins was classified as weak growth inhibition (10-40\% of inhibition), medium growth inhibition (40-80\% of inhibition), or strong growth inhibition (80-100\% of inhibition).

2.5. Biofilm Assays. Bacterial and yeast biofilms were grown in microtiter plates as previously described by Stepanovic et al. [48], with some modifications. Briefly, lectins at concentrations ranging from 31.25 to $250 \mu \mathrm{g} / \mathrm{mL}$ were added to the plates containing microorganisms at $2 \times 10^{6}$ cells $/ \mathrm{mL}$. The plates were then incubated on a horizontal shaker $(120 \mathrm{rpm})$ at $37^{\circ} \mathrm{C}$ for $24 \mathrm{~h}$ for biofilm development. Afterwards, the content of each well was removed, and biofilms were washed twice with $200 \mu \mathrm{L}$ of well sterilized water to remove weakly adherent cells. In order to remove biofilm-entrapped bacterial cells, $200 \mu \mathrm{L}$ of sterile water was added to each well and plates were placed in an ultrasonic bath operating at $50 \mathrm{kHz}$ for 6 min (Sonicor Instruments, Copiague, NY, USA). For the yeast biofilms, each well was scraped vigorously with a pipette tip. Both procedures were previously well established in the laboratory. Serial decimal dilutions from the obtained suspensions were plated on TSA or SDA (depending on the microorganism) to verify the number of viable cells in the biofilms. The agar plates were then incubated for $24 \mathrm{~h}$ at $37^{\circ} \mathrm{C}$, and the total number of colony-forming units (CFU) per unit area $\left(\log \mathrm{CFU} / \mathrm{cm}^{2}\right)$ of the well was counted.

The biofilm biomass was quantified by crystal violet staining method. For the fixation of biofilms, $200 \mu \mathrm{L}$ of $99 \%$ methanol (Romil, UK) was added to each well, and after $15 \mathrm{~min}$ the methanol was removed and the plates were allowed to dry at $25^{\circ} \mathrm{C}$. Then, $200 \mu \mathrm{L}$ of crystal violet stain (Merck, Germany) was added to each well. After $5 \mathrm{~min}$, the unbound dye was removed and wells washed twice with water. Finally, $200 \mu \mathrm{L}$ of acetic acid (33\%, v/v) (Pronalab, Portugal) was added to all wells to dissolve the crystal violet stain, and the optical density was measured at $570 \mathrm{~nm}\left(\mathrm{OD}_{570}\right)$. 
2.6. Statistical Analysis. Statistical analyses were performed by GraphPad Prism version 5.0 software from Microsoft Windows. The data from all the assays were compared using one-way analysis of variance (ANOVA) with the Bonferroni post hoc test. $P<0.01$ was considered to be statistically significant.

\section{Results}

3.1. Lectin Purification. The purities of the lectins were determined by SDS-PAGE, as shown in Figure 1. The Diocleinae lectins displayed a pattern of subunits characteristic of the lectins from that subtribe. The proteins migrated as three bands, consisting of the full-length intact polypeptide chain ( $\alpha$-chain) and two fragments, $\beta$ and $\gamma$. VML migrated as four bands, two major bands (double bands) of approximately 34 and $32 \mathrm{kDa}$ ( $\alpha$-chains) and two minor bands of 22 and $13 \mathrm{kDa}$ (the $\beta$ - and $\gamma$-chains, resp.). LAA migrated as two major bands of $29 \mathrm{kDa}$ (double bands) and two minor bands at approximately $15 \mathrm{kDa}$. A different pattern was observed for BBL, which exhibited only one band of approximately $32 \mathrm{kDa}$. Regarding the algae lectins, BSL and HML exhibited only one band of approximately $10 \mathrm{kDa}$. Furthermore, all lectins showed hemagglutinating activity against rabbit erythrocytes and were fully inhibited by $100 \mathrm{mM}$ D-glucose (Diocleinae lectins), $100 \mathrm{mM}$ D-galactose (VML, LAA, and BBL), and the glycoprotein porcine stomach mucin (algae lectins).

3.2. Effect of Lectins on Planktonic Growth. From all the lectins tested, only 5 (CFL, VML, BBL, HML, and BSL) presented any effect against one or more of the microorganisms. Although these 5 plant and algae lectins were not effective against all bacteria and yeasts, they were all selected for the biofilm assays (Table 1 ).

CFL at $250 \mu \mathrm{g} / \mathrm{mL}$ moderately inhibited the planktonic growth of S. aureus; however, the lowest concentrations of this protein showed weak inhibition. CFL also weakly reduced the growth of $S$. epidermidis at 250 and $125 \mu \mathrm{g} / \mathrm{mL}$. CFL was not able to reduce the growth of the gram-negative bacteria. For the yeasts, CFL moderately inhibited C. albicans at all concentrations, but no effect on C. tropicalis was observed.

Both of the D-galactose-specific lectins (VML and BBL) caused some reduction in the planktonic growth of the microorganisms. VML at $250 \mu \mathrm{g} / \mathrm{mL}$ completely inhibited the planktonic growth of $S$. aureus and S. epidermidis. VML was also able to inhibit, albeit weakly, the growth of $P$. aeruginosa and C. albicans. No effect of BBL was observed against $S$. epidermidis, and only weak inhibition of the other microorganisms was observed.

The algae lectins HML and BSL caused weak growth reductions in $S$. aureus, $S$. epidermidis, and $P$ aeruginosa. Only HML reduced the growth of $K$. oxytoca. Neither of the algae lectins reduced the yeast growth.

3.3. Effect of Lectins on Biofilm Mass and the Number of CFUs. The effects of the lectins on the biomass and the number of biofilm viable cells are shown in Figures 2, 3, 4 , and 5. Interestingly, the lectins were able to prevent the establishment of biomass in the biofilms of the bacteria whose planktonic growth was also sensitive to the lectins. The plant lectins CFL and VML were able to inhibit the biomass formation of $S$. aureus in biofilms (Figure 2(a)), but only VML was able to influence biofilm formation in $S$. epidermidis at the concentration of $250 \mu \mathrm{g} / \mathrm{mL}$ (Figure 2(b)). BSL could decrease the biofilm mass of $S$. aureus at all concentrations (Figure 2(a)); however, HML only caused a small decrease at the highest concentrations (Figure 2(a)). Regarding the gram-negative bacteria, CFL, BBL, and the algae lectins were able to reduce the biomass of $K$. oxytoca to different extents (Figure 2(d)). At $250 \mu \mathrm{g} / \mathrm{mL}, \mathrm{CFL}$ and $\mathrm{HML}$ reduced the biomass of the $P$. aeruginosa biofilm (Figure 2(c)). Although some lectins inhibited the planktonic growth of the yeasts, no lectin was able to reduce the yeast biofilm mass (Figure 3).

After incubating the microorganisms with the lectins for 24 hours, the number of cells was evaluated and expressed as $\log \mathrm{CFU} / \mathrm{cm}^{2}$ (Figures 4 and 5). Similar to the reduction of biomass observed for $S$. aureus and S. epidermidis, a decrease in the number of viable cells in the biofilm was observed in the presence of the highest concentration of VML (Figure 4(a)). Moreover, HML and BSL caused a small decrease in the number of viable cells of $S$. aureus (Figure 4(a)), as did CFL and BBL for $S$. epidermidis (Figure 4(b)). Interestingly, the lectins were unable to decrease the number of viable cells of gram-negative bacteria (Figures 4(c) and 4(d)). Regarding the yeasts, only CFL was able to decrease the number of viable cells in the C. albicans biofilms (Figure 5(a)).

\section{Discussion}

This work investigated the effect of plant and algae lectins on planktonic growth and biofilm formation in both bacteria and yeast. The observed effects of VML on the planktonic growth of $S$. aureus, $S$. epidermidis, and the gram-positive bacteria agreed with the results of other studies [13, 49, 50], which have reported that the lectins isolated from the seeds of Eugenia uniflora (EuniSL) and from the heartwood of Myracrodruon urundeuva display activity against $S$. aureus at low concentrations of 1.5 and $0.58 \mu \mathrm{g} / \mathrm{mL}$, respectively. On the other hand, Costa et al. [51] demonstrated that the Phthirusa pyrifolia leaf lectin (PpyLL) has an MIC at $250 \mu \mathrm{g} / \mathrm{mL}$ to $S$. epidermidis, while it does not inhibit the growth of $S$. aureus. Regarding the gram-negative bacteria, the lectins tested in this study had weak or no effects on planktonic growth (Table 1). The above-referenced EuniSL and the lectin from $M$. urundeuva exhibited MICs of 5 and $4.68 \mu \mathrm{g} / \mathrm{mL}$ to $P$. aeruginosa, respectively, while PpyLL did not have any activity against this bacterium [49-51]. Moreover, the lectin isolated from the seaweed Solieria filiformis [52] reduced the planktonic growth of $P$. aeruginosa, as well as that of other species of gram-negative bacteria, by approximately $25 \%$, but only at concentrations of $1 \mathrm{mg} / \mathrm{mL}$. These differences in the concentrations of the lectins on the reduction of bacterial growth most likely resulted from differences in the strains tested or in the sugar specificity of the different lectins.

The mechanisms by which lectins exert their activity are not well described, but it is believed that their antibacterial activity against gram-positive and gram-negative bacteria 


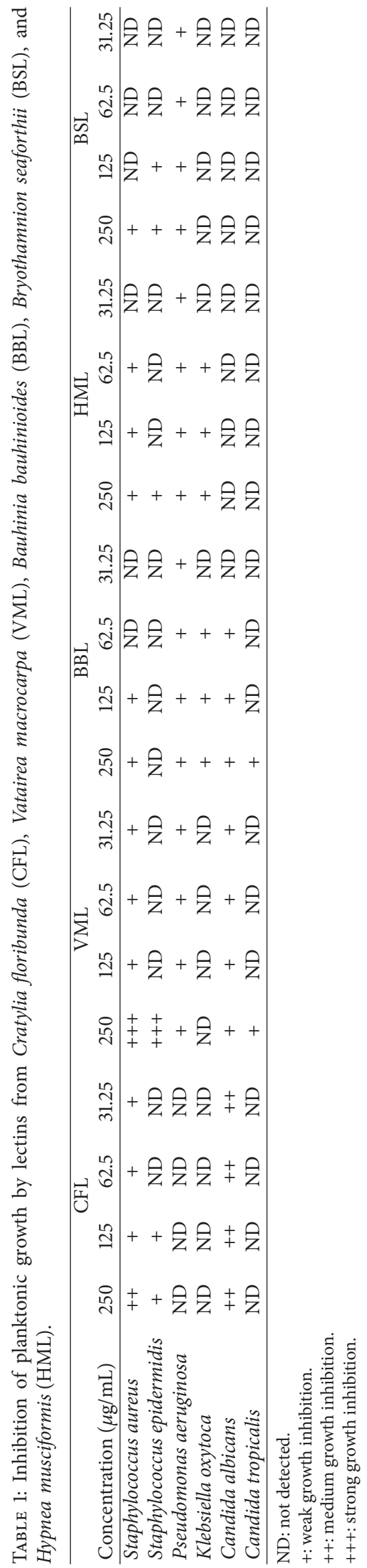




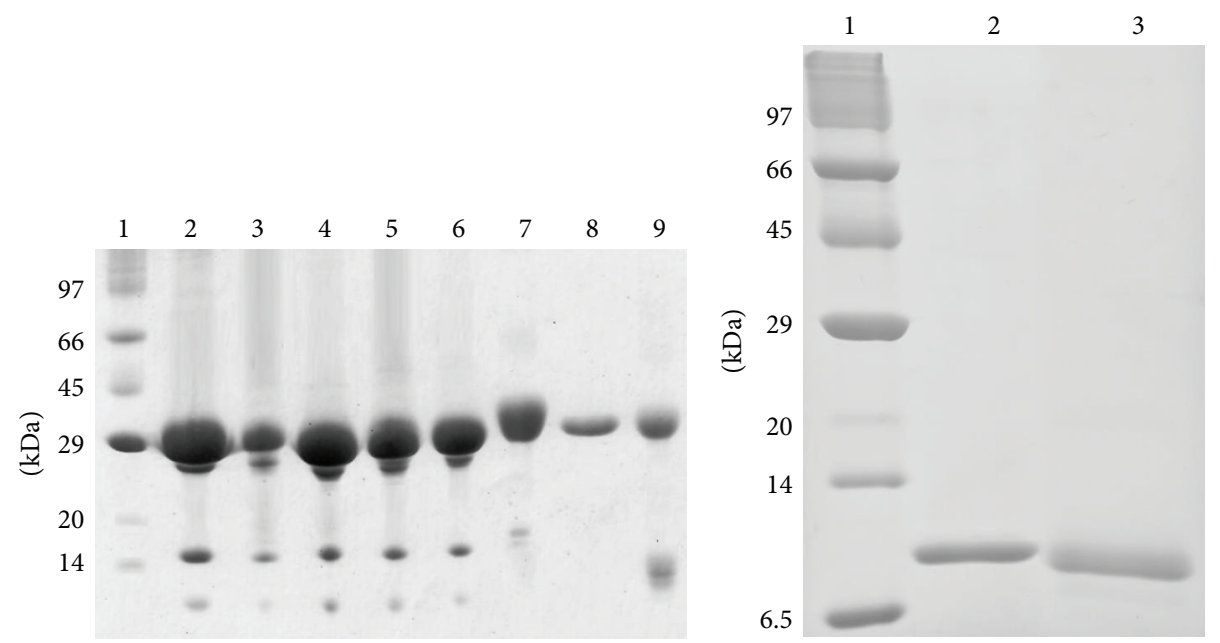

FIGURE 1: SDS-polyacrylamide gel electrophoresis (15\%) (a) Plant lectins. Line 1: Molecularmass markers; line 2: DML; line 3: DRL; line 4: DGL; line 5: DVL; line 6: CFL; line 7: VML; line 8: BBL and line 9: LAA. (b) Algae lectins. Line 1: Molecular mass markers; line 2: BSL and line 3: HML.

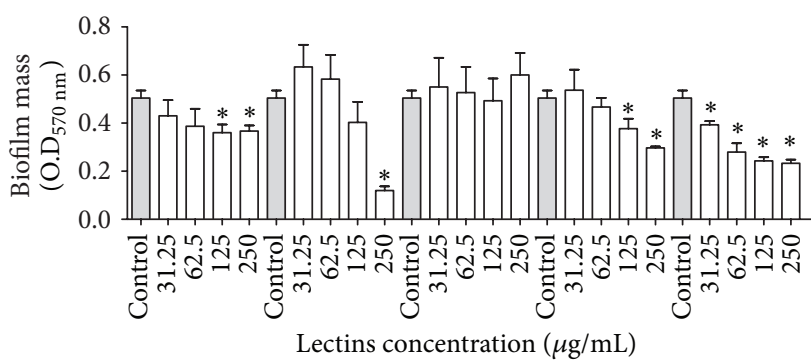

(a)

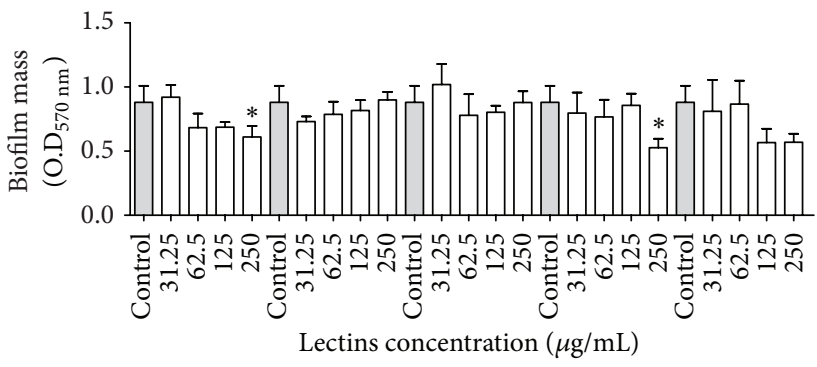

(c)

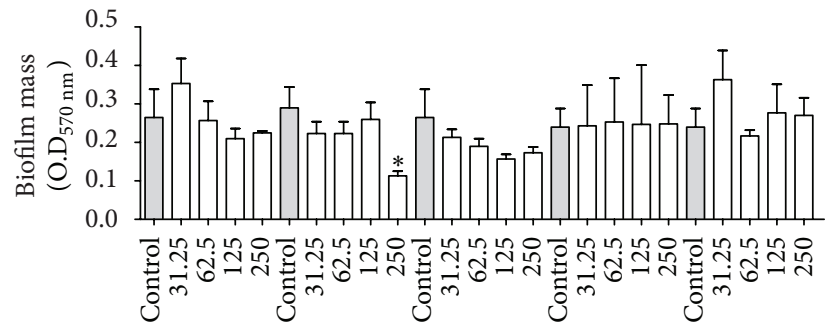

Lectins concentration $(\mu \mathrm{g} / \mathrm{mL})$

(b)

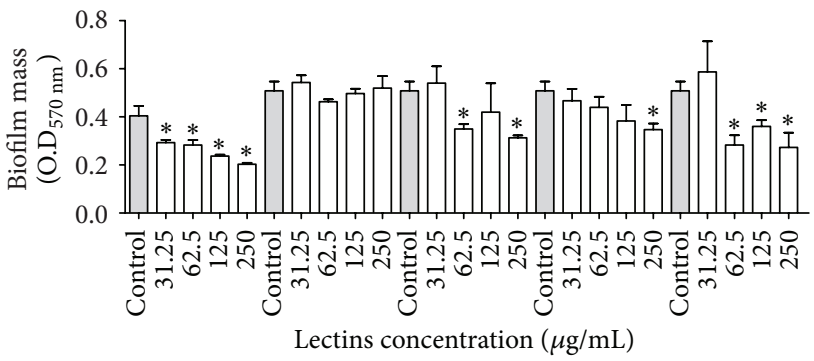

(d)

FIGURE 2: Effects of lectins on the biofilm biomasses of Staphylococcus aureus JKD6008 (a); Staphylococcus epidermidis CECT231 (b); Pseudomonas aeruginosa ATCC10145 (c) and Klebsiella oxytoca ATCC13182 (d). ${ }^{*} P<0.01$ relative to control.

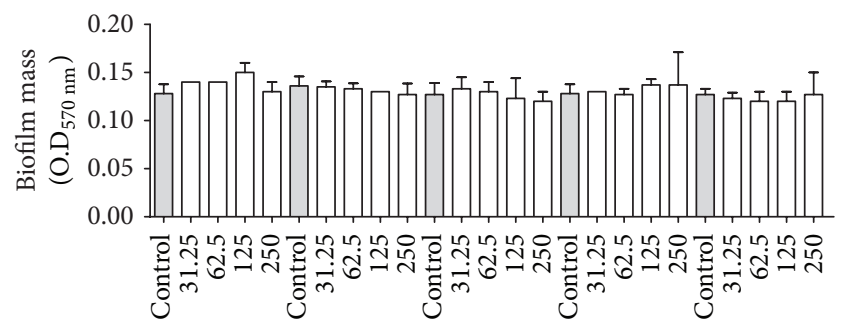

Lectins concentration $(\mu \mathrm{g} / \mathrm{mL})$

(a)

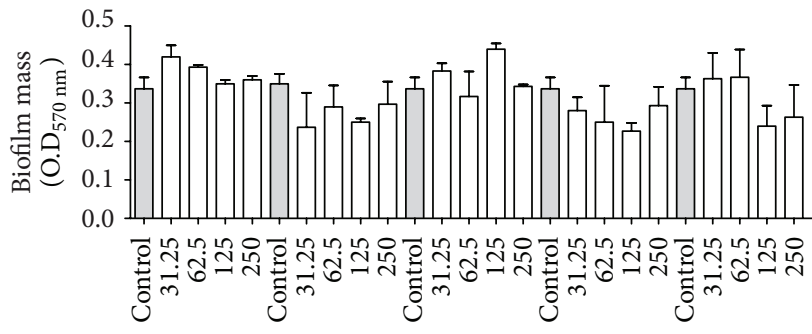

Lectins concentration $(\mu \mathrm{g} / \mathrm{mL})$

(b)

Figure 3: Effects of lectins on the biofilm biomasses of Candida albicans ATCC90028 (a) and Candida tropicalis ATCC750 (b). ${ }^{*} P<0.01$ relative to control. 


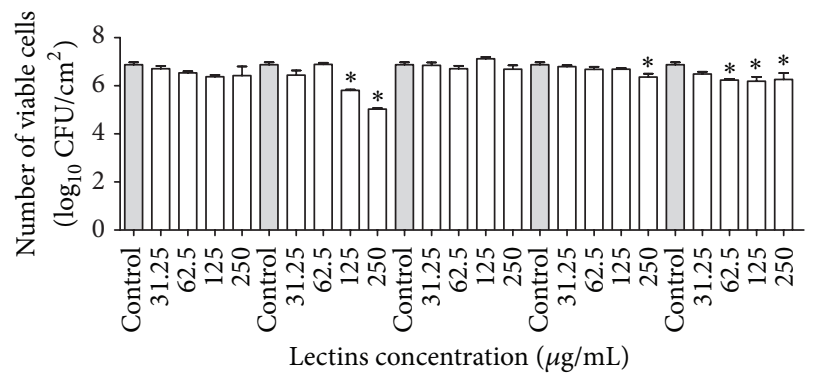

(a)

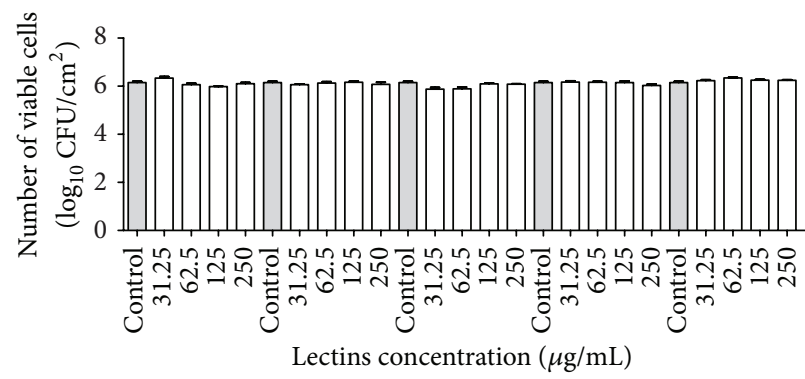

(c)

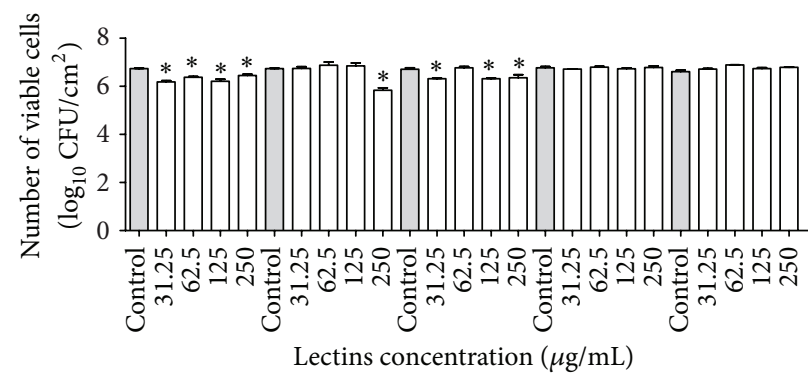

(b)

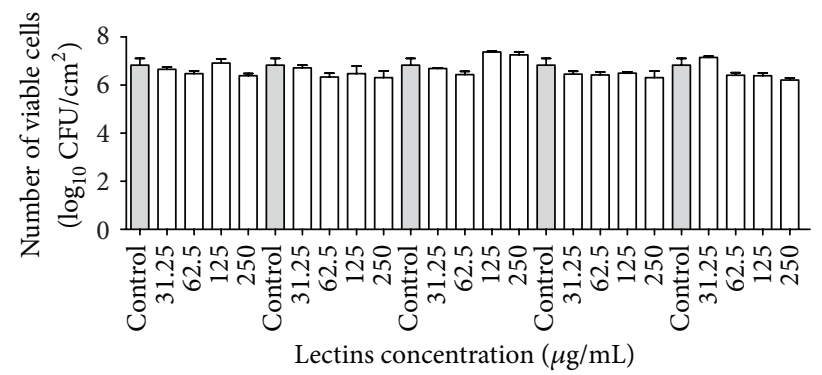

(d)

FIGURE 4: Effects of lectins on the number of viable cells in the biofilms of Staphylococcus aureus JKD6008 (a); Staphylococcus epidermidis CECT231 (b); Pseudomonas aeruginosa ATCC10145 (c) and Klebsiella oxytoca ATCC13182 (d). ${ }^{*} P<0.01$ relative to control.

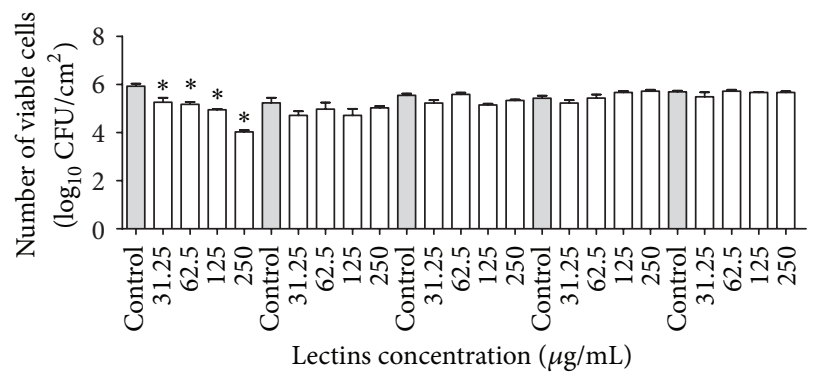

(a)

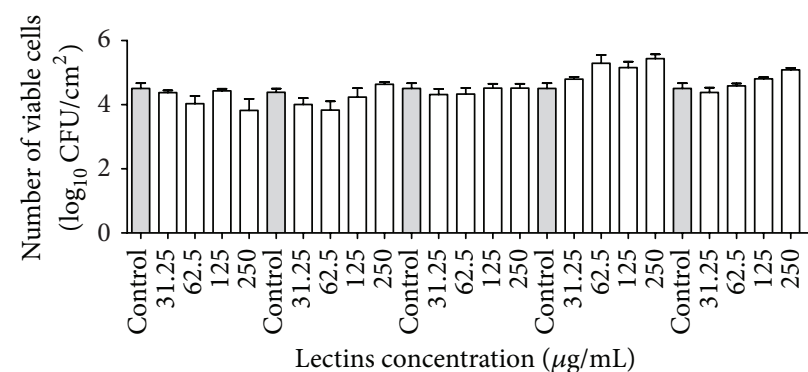

(b)

FIGURE 5: Effects of lectins on the number of viable cells in the biofilms of Candida albicans ATCC90028 (a) and Candida tropicalis ATCC750 (b). ${ }^{*} P<0.01$ relative to control.

occurs through interactions of the lectins with components of the bacterial cell wall, including teichoic and teichuronic acids, peptidoglycans, and lipopolysaccharides [12, 53].

Interestingly, the lectins of the genus Dioclea and CFL are homologous, but only CFL reduced the planktonic growth of the microorganisms. These lectins belong to the subtribe Diocleinae and have a high degree of structural similarity and the same specificity [29]. Despite their high similarity, these lectins induce different responses in biological assays [54, 55]. According to Cavada et al. [26], the differences in biological activity among Diocleinae lectins may result from small changes in the relative orientations of their carbohydratebinding sites, their binding specificity for complex carbohydrates, or their $\mathrm{pH}$-dependent oligomerization state. These factors may explain the observation that only CFL reduced the growth of the microorganisms, while the homologous lectins exhibited no such activity (Table 1).
Despite displaying identical sugar specificity (Dgalactose), VML and BBL also showed different activities against the growth of the microorganisms (Table 1), and their different characteristics may account for their different activities, such as fine variations in their sugar specificities. Furthermore, VML was presented as an N-glycoprotein [56]; however, Silva et al. [44] showed that BBL is not a glycoprotein using sugar analysis.

In this study, the D-galactose-specific lectins VML and $\mathrm{BBL}$ were able to weakly reduce the growth of $C$. albicans (Table 1). According to Santana et al. [57], the lectin isolated from Opuntia ficus cladodes is able to affect the growth of $C$. albicans, reducing fungal growth by approximately 59\%. According to Wong et al. [36], lectins do not directly inhibit fungal growth by changing the structure and/or permeability of the fungal membrane but rather by indirect effects produced by the binding of the lectins to carbohydrates 
on the surface of the fungal cell wall. On the other hand, Melo et al. [58] showed that the lectin isolated from Luetzelburgia auriculata (LAA) inhibits the fungal growth of Saccharomyces cerevisiae. Using transmission electronic microscopy, the authors observed the presence of lectins in the outer portion of the cell wall and in the inner surface of the yeast cell wall bordering the cell membrane. Moreover, their results suggested that the lectin can interfere with the intracellular transport of protons to the external environment [58].

In general, the different lectins were able to reduce the biomass of some bacteria, often in a concentrationdependent manner (Figure 2). For planktonic growth, VML at $250 \mu \mathrm{g} / \mathrm{mL}$ was able to reduce the biomass of $S$. aureus and $S$. epidermidis. CFL also showed a reduction in the biomass of $K$. oxytoca and $P$. aeruginosa, but BBL only showed a reduction in K. oxytoca. VML was more effective at $250 \mu \mathrm{g} / \mathrm{mL}$ (Figure 2). Cavalcante et al. [55] also showed that the lectin isolated from the seeds of Canavalia maritima (ConM) was able to reduce the biomass of Streptococcus mutans biofilms when applied at a concentration of $200 \mu \mathrm{g} / \mathrm{mL}$, which is a concentration similar to that used in this work.

Some lectins isolated from algae have also shown activity against bacterial biofilm formation. For example, lectins from the red algae Bryothamnion triquetrum and Bryothamnion seaforthii were able to attach to the acquired pellicle and reduce the adherence of streptococci strains at $100 \mu \mathrm{g} / \mathrm{mL}$ [33].

Lectins can cause bacterial aggregation [51, 59-61]. Liljemark et al. [62] suggested that the formation of large aggregates causes a decrease in the number of adherent bacteria, which may explain why some of the lectins tested in this study inhibited biofilm formation instead of reducing bacterial growth. Moreover, some studies have indicated that biofilm formation is directly related to the type of LPS produced by the bacteria [63]. Because lectins are able to interact with bacterial LPS [30, 31], the abilities of some lectins to inhibit biofilm formation in gram-negative bacteria may result from interactions between the lectin and LPS, affecting the adherence of these bacteria and thus influencing biofilm formation.

Interestingly, the lectins used in this study reduced the number of viable cells in only the gram-positive bacteria, and only CFL was able to decrease the number of viable cells of C. albicans (Figure 2). Most likely, the reduced number of viable cells in the biofilms of S. aureus and S. epidermidis by VML and in those of $C$. albicans by CFL was caused by the inhibition of the planktonic growth of the microorganisms. Lakhtin et al. [35] showed that lectins of bifidobacterial species and lactobacillus displayed destructive properties towards $C$. albicans and S. aureus biofilms. According to that author, in the presence of the lectins, C. albicans and $S$. aureus biofilm degradation occurs in sequential steps, including biofilm refinement, the appearance of edge cavities, segmentation, the detachment of fragments, and, finally, lysis [35].

In summary, some of the lectins tested here were able to inhibit planktonic growth and/or biofilm formation in the microorganisms. Moreover, the most promising lectins showed differences in activity, which can be explained by the different characteristics of these proteins. On the basis of these findings, further studies will be required to investigate the probable mechanisms of action of these lectins against microorganisms as well as search for new antimicrobial lectins.

\section{Conflict of Interests}

There is no conflict of interests regarding this paper.

\section{Authors' Contribution}

All authors contributed to and approved this paper.

\section{Acknowledgments}

This study was supported by the CAPES (Brazil) under the BEX NT 2052/11NT3 Project, by the IBB-CEB and FCT (Portugal), by the European Community Fund FEDER, and by the COMPETE Program under the auspices of the PTDC/SAUESA/646091/2006/FCOMP-01-0124-FEDER-007480 Project. Kyria Santiago Nascimento, Alexandre Holanda Sampaio, Benildo Sousa Cavada, and Edson Holanda Teixeira are Senior Fellows of CNPq. Mr. David Martin helped with the English editing of the paper that was also revised by AJE (American Journal Experts).

\section{References}

[1] M. R. Hall, E. McGillicuddy, and L. J. Kaplan, "Biofilm: basic principles, pathophysiology, and implications for clinicians," Surgical Infections, vol. 15, no. 1, pp. 1-7, 2014.

[2] D. Davies, "Understanding biofilm resistance to antibacterial agents," Nature Reviews Drug Discovery, vol. 2, no. 2, pp. 114122, 2003.

[3] J. Masák, A. Cejková, O. Schreiberová, and T. Rezanka, "Pseudomonas biofilms: possibilities of their control," FEMS Microbiology Ecology, 2014.

[4] L. C. Martínez and V. Vadyvaloo, "Mechanisms of posttranscriptional gene regulation in bacterial biofilms," Frontiers in Cellular and Infection Microbiology, vol. 25, no. 4, pp. 1-15, 2014.

[5] L. R. Mulcahy, V. M. Isabella, and K. Lewis, "Pseudomonas aeruginosa biofilms in disease," Microbial Ecology, 2013.

[6] D. L. Hamilos, "Host-microbial interactions in patients with chronic rhinosinusitis," Journal of Allergy and Clinical Immunology, vol. 133, no. 3, pp. 640-653, 2014.

[7] S. P. Lopes, N. F. Azevedo, and M. O. Pereira, "Microbiome in cystic fibrosis: shaping polymicrobial interactions for advances in antibiotic therapy," Critical Reviews in Microbiology, 2014.

[8] D. J. Stickler, "Clinical complications of urinary catheters caused by crystalline biofilms: something needs to be done," Journal of Internal Medicine, 2014

[9] M. Abdallah, C. Benoliel, D. Drider, P. Dhulster, and N. E. Chihib, "Biofilm formation and persistence on abiotic surfaces in the context of food and medical environments," Archives of Microbiology, 2014. 
[10] M. S. Blackledge, R. J. Worthington, and C. Melander, "Biologically inspired strategies for combating bacterial biofilms," Current Opinion in Pharmacology, vol. 13, no. 5, pp. 699-706, 2013.

[11] J. E. Nett, "Future directions for anti-biofilm therapeutics targeting Candida," Expert Review of Anti-Infective Therapy, vol. 12, no. 3, pp. 375-382, 2014.

[12] P. M. G. Paiva, F. S. Gomes, T. H. Napoleão, R. A. Sá, M. T. S. Correia, and L. C. B. B. Coelho, "Antimicrobial activity of secondary metabolites and lectins from plants," Current Research, Technology and Education Topics in Applied Microbiology and Microbial Biotechnology, vol. 1, pp. 396-406, 2010.

[13] L. P. Albuquerque, G. M. Santana, T. H. Napoleão, L. C. Coelho, M. V. Silva, and P. M. Paiva, "Antifungal activity of Microgramma vacciniifolia rhizome lectin on genetically distinct Fusarium oxysporum f. sp. lycopersici races,", Applied Biochemistry and Biotechnology, vol. 172, no. 2, pp. 1098-1105, 2014.

[14] G. B. Klafke, S. Borsuk, R. A. Gonçales et al., "Inhibition of initial adhesion of oral bacteria through a lectin from Bauhinia variegata L. var. variegata expressed in Escherichia coli," Journal of Applied Microbiology, vol. 115, no. 5, pp. 1222-1230, 2013.

[15] E. J. M. van Damme, W. J. Peumans, A. Barre, and P. Rougé, "Plant lectins: a composite of several distinct families of structurally and evolutionary related proteins with diverse biological roles," Critical Reviews in Plant Sciences, vol. 17, no. 6, pp. 575692, 1998.

[16] B. Kimble, G. R. Nieto, and D. R. Perez, "Characterization of influenza virus sialic acid receptors in minor poultry species," Virology Journal, vol. 7, article 365, 2010.

[17] B. Gerland, A. Goudot, C. Ligeour et al., "Structure binding relationship of galactosylated Glycoclusters toward Pseudomonas aeruginosa lectin LecA using a DNA-based carbohydrate microarray," Bioconjugate Chemistry, vol. 25, no. 2, pp. 379-392, 2014.

[18] P. M. Collins, K. Bum-Erdene, X. Yu, and H. Blanchard, "Galectin-3 interactions with glycosphingolipids," Journal of Molecular Biology, vol. 426, no. 7, pp. 1439-1451, 2014.

[19] A. Malik, J. Lee, and J. Lee, "Community-based network study of protein-carbohydrate interactions in plant lectins using glycan array data," PLoS ONE, vol. 9, no. 4, Article ID e95480, 2014.

[20] P. V. Murphy, S. André, and H.-J. Gabius, “The third dimension of reading the sugar code by lectins: design of glycoclusters with cyclic scaffolds as tools with the aim to define correlations between spatial presentation and activity," Molecules, vol. 18, no. 4, pp. 4026-4053, 2013.

[21] M. Kitada, Y. Kuroda, and M. Dezawa, "Lectins as a tool for detecting neural stem/progenitor cells in the adult mouse brain," Anatomical Record, vol. 294, no. 2, pp. 305-321, 2011.

[22] V. J. Osterne, M. Q. Santiago, V. R. Pinto-Junior et al., "Purification, partial characterization, and CNBr-Sepharose immobilization of a vasorelaxant glucose/mannose lectin from Canavalia virosa seeds," Applied Biochemistry and Biotechnology, vol. 172, no. 7, pp. 3342-3353, 2014.

[23] G. de Sousa Ferreira Soares, A. M. S. Assreuy, C. A. de Almeida Gadelha et al., "Purification and biological activities of abelmoschus esculentus seed lectin," Protein Journal, vol. 31, no. 8, pp. 674-680, 2012.

[24] I. L. Barroso-Neto, R. C. Simões, B. A. Rocha et al., "Vasorelaxant activity of Canavalia grandiflora seed lectin: a structural analysis," Archives of Biochemistry and Biophysics, vol. 543, pp. 31-39, 2014.
[25] F. O. Silva, P. Santos, E. O. Figueirôa et al., "Antiproliferative effect of Canavalia brasiliensis lectin on B16F10 cells," Research in Veterinary Science, vol. 96, no. 2, pp. 276-282, 2014.

[26] B. S. Cavada, T. Barbosa, S. Arruda, T. B. Grangeiro, and M. Barral-Netto, "Revisiting proteus: do minor changes in lectin structure matter in biological activity? Lessons from and potential biotechnological uses of the Diocleinae subtribe lectins," Current Protein and Peptide Science, vol. 2, no. 2, pp. 123-135, 2001.

[27] H. Sahly, Y. Keisari, E. Crouch, N. Sharon, and I. Ofek, "Recognition of bacterial surface polysaccharides by lectins of the innate immune system and its contribution to defense against infection: the case of pulmonary pathogens," Infection and Immunity, vol. 76, no. 4, pp. 1322-1332, 2008.

[28] M. A. de Vasconcelos, C. O. Cunha, F. V. Sousa Arruda et al., "Lectin from canavalia brasiliensis seeds (ConBr) is a valuable biotechnological tool to stimulate the growth of rhizobium tropici in vitro," Molecules, vol. 17, no. 5, pp. 5244-5254, 2012.

[29] M. Strathmann, J. Wingender, and H.-C. Flemming, "Application of fluorescently labelled lectins for the visualization and biochemical characterization of polysaccharides in biofilms of Pseudomonas aeruginosa," Journal of Microbiological Methods, vol. 50, no. 3, pp. 237-248, 2002.

[30] S. Biswas, A. Saroha, and H. R. Das, "A lectin from Sesbania aculeata (Dhaincha) roots and its possible function," Biochemistry, vol. 74, no. 3, pp. 329-335, 2009.

[31] P. Agrawal, S. Kumar, Y. K. Jaiswal, H. R. Das, and R. H. Das, "A Mesorhizobium lipopolysaccharide (LPS) specific lectin (CRL) from the roots of nodulating host plant, Cicer arietinum," Biochimie, vol. 93, no. 3, pp. 440-449, 2011.

[32] E. H. Teixeira, M. H. Napimoga, V. A. Carneiro et al., "In vitro inhibition of Streptococci binding to enamel acquired pellicle by plant lectins," Journal of Applied Microbiology, vol. 101, no. 1, pp. 111-116, 2006.

[33] E. H. Teixeira, M. H. Napimoga, V. A. Carneiro et al., "In vitro inhibition of oral streptococci binding to the acquired pellicle by algal lectins," Journal of Applied Microbiology, vol. 103, no. 4, pp. 1001-1006, 2007.

[34] B. Islam, S. N. Khan, A. Naeem, V. Sharma, and A. U. Khan, "Novel effect of plant lectins on the inhibition of Streptococcus mutans biofilm formation on saliva-coated surface," Journal of Applied Microbiology, vol. 106, no. 5, pp. 1682-1689, 2009.

[35] M. Lakhtin, V. Alyoshkin, V. Lakhtin, S. Afanasyev, L. Pozhalostina, and V. Pospelova, "Probiotic lactobacillus and bifidobacterial lectins against Candida albicans and Staphylococcus aureus clinical strains: new class of the pathogen biofilm destructors," Probiotics and Antimicrobial Proteins, vol. 2, no. 3, pp. 186-196, 2010.

[36] J. H. Wong, T. B. Ng, R. C. F. Cheung et al., "Proteins with antifungal properties and other medicinal applications from plants and mushrooms," Applied Microbiology and Biotechnology, vol. 87, no. 4, pp. 1221-1235, 2010.

[37] B. P. Howden, T. P. Stinear, D. L. Allen, P. D. R. Johnson, P. B. Ward, and J. K. Davies, "Genomic analysis reveals a point mutation in the two-component sensor gene graS that leads to intermediate vancomycin resistance in clinical Staphylococcus aureus," Antimicrobial Agents and Chemotherapy, vol. 52, no. 10, pp. 3755-3762, 2008.

[38] R. A. Moreira, A. C. O. Monteiro, A. C. G. Horta, J. T. A. Oliveira, and B. S. Cavada, "Isolation and characterization of Dioclea altissima var. megacarpa seed lectin," Phytochemistry, vol. 46, no. 1, pp. 139-144, 1997. 
[39] B. S. Cavada, T. B. Grangeiro, M. V. Ramos, E. F. Cordeiro, J. T. A. Oliveira, and R. V. Moreira, "Isolation and partial characterization of a lectin from Dioclea rostrata benth seeds," Revista Brasileira de Fisiologia Vegetal, vol. 8, no. 1, pp. 31-36, 1996.

[40] I. M. Vasconcelos, R. A. Moreira, and J. T. A. Oliveira, "Purification and partial characterization of a lectin from the seeds of Dioclea guianensis," Journal of Food Biochemistry, vol. 15, pp. 137-154, 1991.

[41] R. V. Moreira, E. F. Cordeiro, M. V. Ramos et al., "Isolation and partial characterization of a lectin from seeds of Dioclea violacea," Revista Brasileira de Botânica, vol. 8, no. 1, pp. 23-29, 1996.

[42] J. T. A. Oliveira, B. S. Cavada, and R. A. Moreira, "Isolation and partial characterization of a lectin from Cratylia floribunda Mart. seeds," Revista Brasileira de Botânica, vol. 14, pp. 63-68, 1991.

[43] B. S. Cavada, C. F. Santos, T. B. Grangeiro et al., "Purification and characterization of a lectin from seeds of Vatairea macrocarpa duke," Phytochemistry, vol. 49, no. 3, pp. 675-680, 1998.

[44] H. C. Silva, A. U. Bari, F. N. Pereira-Júnior et al., "Purification and partial characterization of a new pro-inflammatory lectin from Bauhinia bauhinioides mart (caesalpinoideae) seeds," Protein and Peptide Letters, vol. 18, no. 4, pp. 396-402, 2011.

[45] J. T. A. Oliveira, V. M. M. Melo, M. F. L. Câmara et al., "Purification and physicochemical characterization of a cotyledonary lectin from Luetzelburgia auriculata," Phytochemistry, vol. 61, no. 3, pp. 301-310, 2002.

[46] I. L. Ainonz, A. H. Sampaio, A. L. P. Freitas, N. M. B. Benevides, and S. Mapurunga, "Comparative study on hemagglutinins from the red algae Bryothamnion seaforthii and Bryothamnion triquetrum," Revista Brasileira de Fisiologia Vegetal, vol. 7, no. 1, pp. $15-19,1995$.

[47] C. S. Nagano, F. B. M. B. Moreno, C. Bloch Jr. et al., "Purification and characterization of a new lectin from the red marine alga Hypnea musciformis," Protein and Peptide Letters, vol. 9, no. 2, pp. 159-165, 2002.

[48] S. Stepanovic, D. Vukovic, I. Dakic, B. Savic, and M. SvabicVlahovic, "A modified microtiter-plate test for quantification of staphylococcal biofilm formation," Journal of Microbiological Methods, vol. 40, no. 2, pp. 175-179, 2000.

[49] M. D. L. Oliveira, C. A. S. Andrade, N. S. Santos-Magalhães et al., "Purification of a lectin from Eugenia uniflora L. seeds and its potential antibacterial activity," Letters in Applied Microbiology, vol. 46, no. 3, pp. 371-376, 2008.

[50] R. A. Sá, F. S. Gomes, T. H. Napoleão et al., "Antibacterial and antifungal activities of Myracrodruon urundeuva heartwood," Wood Science and Technology, vol. 43, no. 1-2, pp. 85-95, 2009.

[51] R. M. P. B. Costa, A. F. M. Vaz, M. L. V. Oliva, L. C. B. B. Coelho, M. T. S. Correia, and M. G. Carneiro-da-Cunha, "A new mistletoe Phthirusa pyrifolia leaf lectin with antimicrobial properties," Process Biochemistry, vol. 45, no. 4, pp. 526-533, 2010.

[52] M. L. Holanda, V. M. M. Melo, L. M. C. M. Silva, R. C. N. Amorim, M. G. Pereira, and N. M. B. Benevides, "Differential activity of a lectin from Solieria filiformis against human pathogenic bacteria," Brazilian Journal of Medical and Biological Research, vol. 38, no. 12, pp. 1769-1773, 2005.

[53] Y. Bourne, A. Ayouba, P. Rouge, and C. Cambillau, "Interaction of a legume lectin with two components of the bacterial cell wall. A crystallographic study," Journal of Biological Chemistry, vol. 269, no. 13, pp. 9429-9435, 1994.
[54] M. J. B. Bezerra, N. V. F. C. Rodrigues, A. D. F. Pires et al., "Crystal structure of Dioclea violacea lectin and a comparative study of vasorelaxant properties with Dioclea rostrata lectin," International Journal of Biochemistry and Cell Biology, vol. 45, no. 4, pp. 807-815, 2013.

[55] T. T. A. Cavalcante, B. A. M. da Rocha, V. A. Carneiro et al., "Effect of lectins from diocleinae subtribe against oral streptococci," Molecules, vol. 16, no. 5, pp. 3530-3543, 2011.

[56] J. J. Calvete, C. F. Santos, K. Mann et al., "Amino acid sequence, glycan structure, and proteolytic processing of the lectin of Vatairea macrocarpa seeds," FEBS Letters, vol. 425, no. 2, pp. 286-292, 1998.

[57] G. M. S. Santana, L. P. Albuquerque, D. A. Simões, L. C. B. B. Coelho, P. M. G. Paiva, and N. B. Gusmão, "Isolation of lectin from Opuntia ficus indica cladodes," Acta Horticulturae, vol. 811, pp. 281-286, 2009.

[58] V. M. M. Melo, I. M. Vasconcelos, V. M. Gomes, M. da Cunha, A. A. Soares, and J. T. A. Oliveira, "A cotyledonary agglutinin from Luetzelburgia auriculata inhibits the fungal growth of Colletotrichum lindemuthianum, Fusarium solani and Aspergillus niger and impairs glucose-stimulated acidification of the incubation medium by Saccharomyces cerevisiae cells," Plant Science, vol. 169, no. 3, pp. 629-639, 2005.

[59] S. Ratanapo, W. Ngamjunyaporn, and M. Chulavatnatol, "Sialic acid binding lectins from leaf of mulberry (Morus alba)," Plant Science, vol. 139, no. 2, pp. 141-148, 1998.

[60] J. Sun, L. Wang, B. Wang et al., "Purification and characterisation of a natural lectin from the serum of the shrimp Litopenaeus vannamei," Fish and Shellfish Immunology, vol. 23, no. 2, pp. 292-299, 2007.

[61] A. A. Melo, R. F. Carneiro, W. M. Silva et al., "HGA-2, a novel galactoside-binding lectin from the sea cucumber Holothuria grisea binds to bacterial cells," International Journal of Biological Macromolecules, vol. 64, pp. 435-442, 2014.

[62] W. F. Liljemark, C. G. Bloomquist, and G. R. Germaine, "Effect of bacterial aggregation on the adherence of oral streptococci to hydroxyapatite," Infection and Immunity, vol. 31, no. 3, pp. 935941, 1981.

[63] H. L. Rocchetta, L. L. Burrows, and J. S. Lam, "Genetics of Oantigen biosynthesis in Pseudomonas aeruginosa," Microbiology and Molecular Biology Reviews, vol. 63, no. 3, pp. 523-553, 1999. 

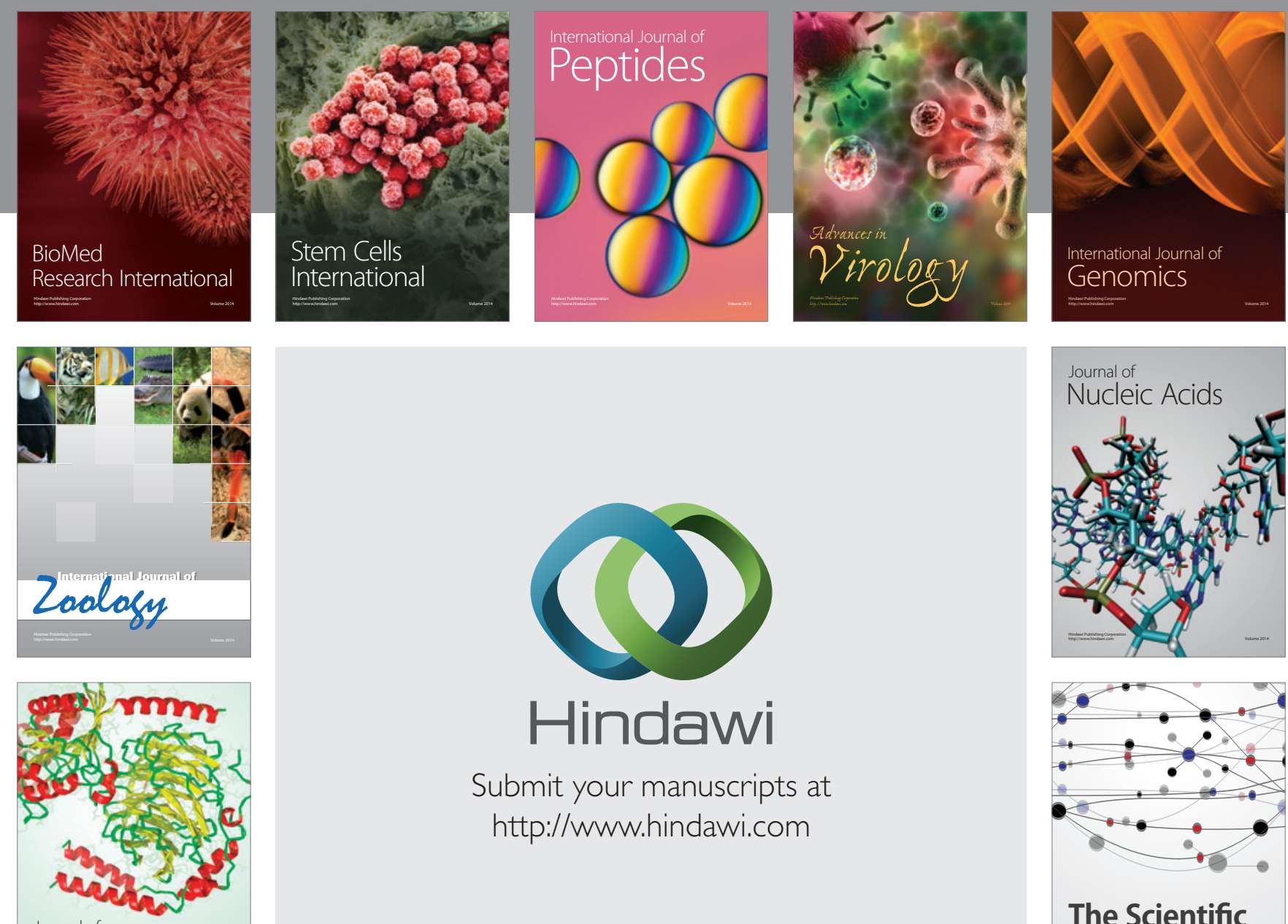

Submit your manuscripts at

http://www.hindawi.com

Journal of
Signal Transduction
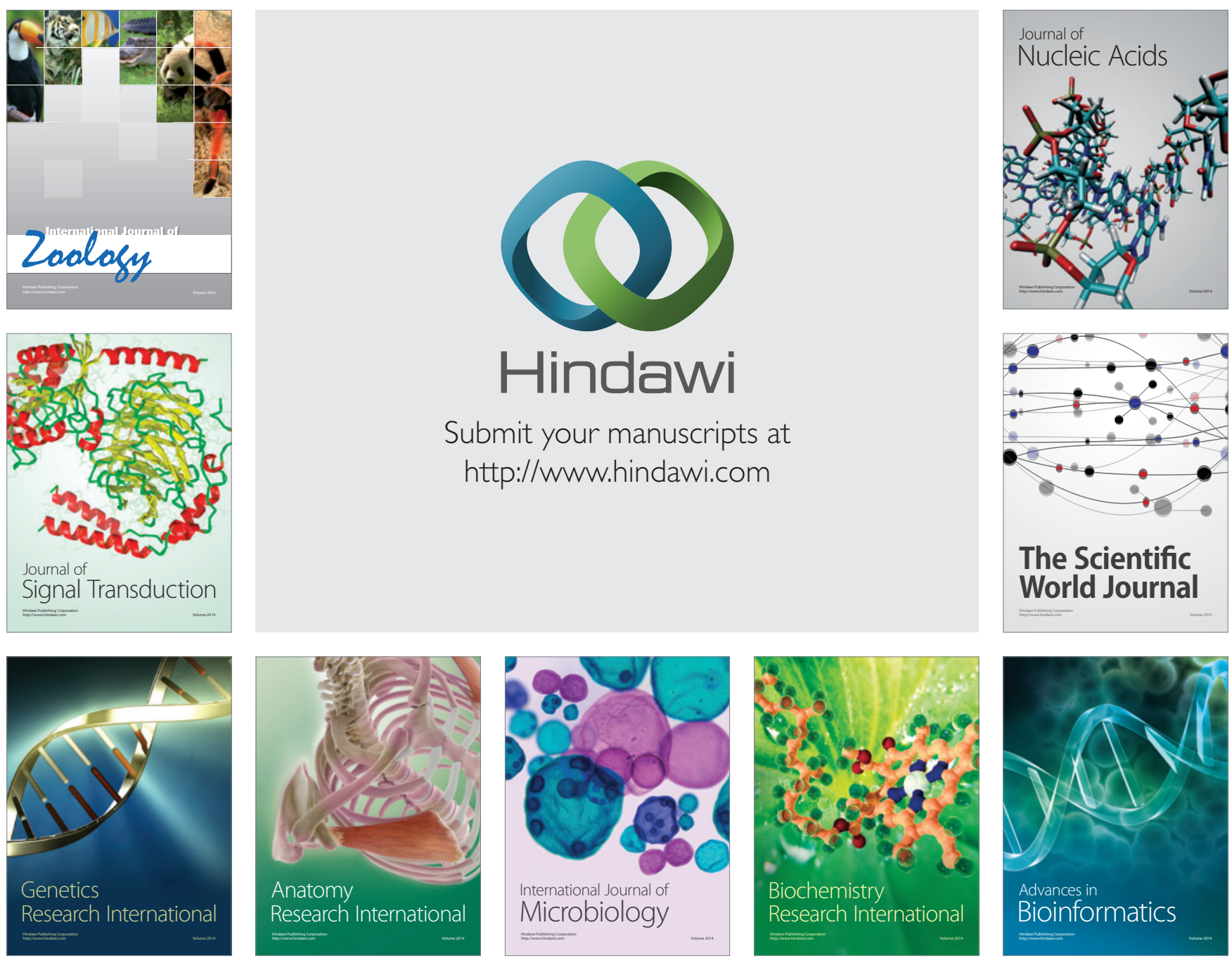

The Scientific World Journal
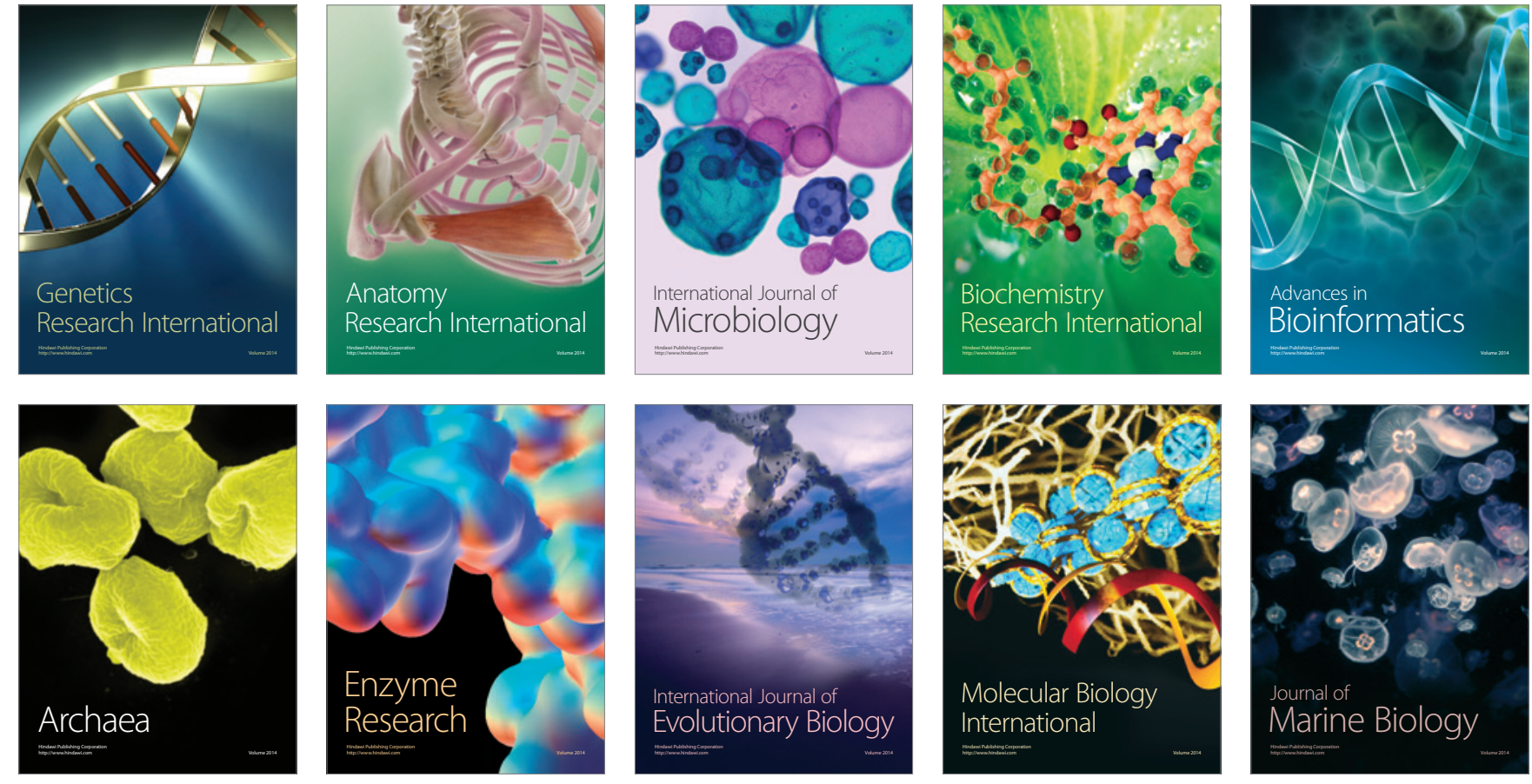